Omni-Akuatika, 11 (2): 1-6, 2017
ISSN: 1858-3873 print / 2476-9347 online
Review

\title{
Microplastics Monitoring in Marine Environment
}

\author{
Agung Dhamar Syakti ${ }^{1,2}{ }^{*}$ \\ 1. Center for Maritime Biosciences Studies - Institute for Sciences and Community Service, Jenderal Soedirman \\ University, Kampus Karangwangkal, Jl. dr. Suparno, Purwokerto 53123, Indonesia
}

2.Marine Science and Fisheries Faculty - Raja Ali Haji Maritime University, JI. Politeknik SenggarangTanjungpinang, Riau Islands Province, 29100, Indonesia

${ }^{*}$ Corresponding author: agungsyakti@chemist.com

Received 19 November 2017; Accepted 27 November 2017; Available online 28 November 2017

\begin{abstract}
This review summarizes the need for future spatiotemporal comparisons of microplastics abundance across marine environment, through standardized methods for microplastic sampling and analysis in sea water, beach and seabed sediment and marine organism. Pretreatment of the sample prior to the elimination of organic matter should be done using appropriate reagents was also described. Extraction of microplastics from environmental matrices is based on the different density of targeted microplastics with saturated salt solutions $\left(\mathrm{NaCl}, \mathrm{Nal}, \mathrm{CaCl}_{2}, \mathrm{ZnCl}_{2}\right.$ and lithium metatungstate). Quantification can be achieved by microscopic techniques (binocular, stereomicroscope, fluorescence microscope and scanning electron microscope) and discussion on identification methods including FTIR, Pyr-GC/MS and Raman spectroscopy will be provided. This review also endorse the important of further study regarding the fate and impact of microplastics on marine biota and human health, especially when we acknowledge that co-pollution may occur during the transport on microplastics in marine environment.
\end{abstract}

Keywords: marine pollution, environmental chemistry, co- pollutants, microplastics, marine debris

\section{Introduction}

For worldwide scientific communities, the term of "marine debris and microplastic" are rose up in last two decades but such term is relatively newly introduced in Indonesia (Dewi et al., 2015; Rochman et al., 2015; Cordoba and Wahyudi, 2016; Syakti et al., 2017). There is several definitions of microplastics including GESAMP (2016) and UNEP (2016). The most widely used definition is referred to the particles less than $5 \mathrm{~mm}$ in their longest dimensions. This review proposes a practical term of microplastic related with aquatic sciences. The term of "microplastics" describes plastic debris $<5 \mathrm{~mm}$ in size (wide, length, thickness or diameter) which can be harmful for aquatic life. In fact, plastic has been globally used as multitude of product of the different scale mainly for packaging and broad range application including automobile, medical and building materials. Annual global production continues to grow for more than 50 years and reached to 322 million tons in 2015 (PlasticEurope, 2016). Accordingly, In Indonesia, the total plastic waste was predicted reached 9.52 million tons in 2019 (KLHK, 2017). Using an assumption proposed by (Van Cauwenberghe et al., 2015) and a model based on Jambeck et al. (2015), $10 \%$ plastic waste will end up in the sea by year and may results in total 187.2 millions tons accumulation of plastic waste in Indonesia marine ecosystem in 2015. Indonesia has already been actively participating in global and regional High Level Meeting in order to increase public awareness and engagement to reduce marine plastic debris by $70 \%$ in 2020 (CMMA, 2017). Despite a wide array of commitments being made to address this emerging issue, knowledge on marine plastics, particularly 
microplastics and its impacts, still remains rather limited. So that why, assessment of marine debris and microplastic pollution, standardized methods and protocols for sampling and laboratory analysis, understanding of the microplastics pollution impact in marine organisms should be developed and standardized even thought there is still occurs methodological limitations encountered for microplastics research.

This review paper describes the essential tool for monitoring program of microplastics extraction, enumeration and identification methods. Accordingly, we aim to promote a standardized monitoring program for microplastics in Indonesia marine ecosystem. We focus on three different environmental matrices i.e. water, sediment and marine biota.

\section{Microplastic Sampling and Pretreatment}

\subsection{Seawater}

Samples can be collected from the surface, middle and bottom layer through difference trawl model with a rectangular opening and a net connected with a collecting bag (Figure 1).

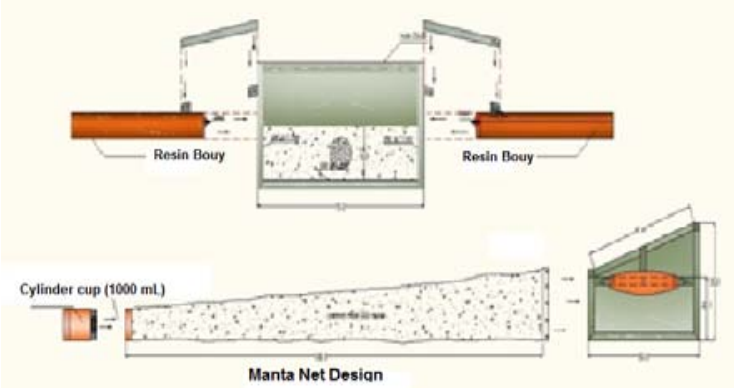

Figure 1. Mini trawl with Manta/Neuston Net type

The system can be made with 60 to $80 \mathrm{~cm}$ net diameter sizes with a rigid frame construction and buoyant aquaplanes made by a resin mixture maintain a continuous rectangular net opening at the surface with a maximum depth of $30 \mathrm{~cm}$. Typically applied with mesh size ranged from $20-1,000 \mu \mathrm{m}$, the overall system called e.g. DiSalvo neuston net (DiSalvo, 1988), Manta Net (Syakti et al., 2017) and AVANI trawl (Eriksen et al., 2018).

\subsection{Sediment}

Sediment samples are generally taken from beach and seabed. For the beach sampling, it is recommended to collect two parallel transect lines near the high or low tide lines. The samples are taken from several 0.25 $x$ 0.25-meter quadrat in transect lines (Wessel et al., 2016). Beach sediment samples are collected from the topmost $1 \mathrm{~cm}$ (Leibezeit and Dubaish, 2012), $3 \mathrm{~cm}$ (Manthalon and Hill, 2014), $5 \mathrm{~cm}$ (Corcorana et al., 2015) and $10 \mathrm{~cm}$ ( $\mathrm{Ng}$ and Obbard, 2006) in each quadrat. Seabed sediment sampling can be done using a box-corer (Corconara et al., 2015; Cordoba and Wahyudi, 2016). Beach and seabed samples could be collected using non-plastic sampling tools i.e. stainless steel shovel.

After sampling, the sediment can be transported to the laboratory by using a glass or aluminum foil container and then stored at $4{ }^{\circ} \mathrm{C}$ prior to further analysis. The sediment samples are processed through a series of pre-treatment steps: drying at different temperature e.g. $50{ }^{\circ} \mathrm{C}$ and $60^{\circ} \mathrm{C}$ (Manthalon and Hill, 2014; Qiu et al., 2015), sieving on a successive mesh (e.g. $<5$ $\mathrm{mm},<1 \mathrm{~mm}$ and $<200 \mu \mathrm{m}$ ), drying for mass at temperature below $60{ }^{\circ} \mathrm{C}$ (Osswald et al., 2006).

\subsection{Marine Biota}

Most studies related with ingested plastic have been recorded in fishes (Halstead et al., 2018) through direct sampling in the sea (Lusher et al., 2013) or from fish markets (Rochman et al., 2015) or even in fish larvae (Steer et al., 2017). Recently the research works also targeted other organisms such as mussels and lugworms (Van Cauwenberghe et al., 2015), crab (Watt et al., 2014), and zooplankton (Cole et al., 2013). Generally, for the fishes or macroinvertebrate, the relative data that should be recorded included their sex, length, weight, girth, etc before dissection to obtain the gastrointestinal tracts for analysis. Fish liver was also weighted to calculate the hepato-somatic index. Digestive tracts of respective biota are removed and then the stomach was flushed by shearwater to rush out any food and ingested microplastics, dried and stored before extraction. Biotic samples storages can be done by fixative technique using $4 \%$ formaldehyde and $70 \%$ ethanol but some polymers can be damaged, thus an alternative storage of biotic samples can be done by simple freezing (Lusher et al., 2017).

\section{Microplastic Extraction}

From different pretreated samples i.e. water, sediment, and biota, in order to remove organic matter remaining on the surface of the plastic and to help further identification by FTIR, 
$30 \%$ of $\mathrm{H}_{2} \mathrm{O}_{2}$ should be added into the solution. Other oxidator used in microplastic research are chloride acid $(\mathrm{HCl})$, nitric acid $\left(\mathrm{HNO}_{3}\right)$, potassium hydroxide $(\mathrm{KOH})$ and enzymes (Nuelle et al., 2014; Cole et al., 2014). After filtering and drying, the sediment is added with high density saturated solution under quickly stirring. Typically, a saturated sodium chloride $(\mathrm{NaCl})$ solution with a density of $1.202 \mathrm{~g} / \mathrm{mL}$ is used for separating microplastics from sediment and sand. Sodium iodide (Nal), calcium chloride $\left(\mathrm{CaCl}_{2}\right)$, zinc chloride $\left(\mathrm{ZnCl}_{2}\right)$, and lithium metatungstate (LMT) can also be used with density $1.98 \mathrm{~g} / \mathrm{mL}, 1.46 \mathrm{~g} / \mathrm{mL}, 2.91 \mathrm{~g} / \mathrm{mL}$ and $3.7 \mathrm{~g} / \mathrm{mL}$ respectively for microplastic extraction. Table 1 . showed the different density of plastic polymers and the saturated salt that can be used to float the respective plastic type and polymers.

Table 1. Density of polymers and appropriate solution for extraction.

\begin{tabular}{|c|c|c|}
\hline $\begin{array}{l}\text { Polymers } \\
\text { /fibers }\end{array}$ & $\begin{array}{l}\text { Density } \\
(\mathrm{g} / \mathrm{mL})\end{array}$ & Appropriate Salt Solution \\
\hline PETE & 1.38 & $\mathrm{Nal}, \mathrm{ZnCl}_{2}, \mathrm{LMT}$ \\
\hline LDPE & 0.92 & All salt \\
\hline HDPE & 0.95 & All salt \\
\hline PS & 1.05 & All salt \\
\hline PP & $0.87-1.01$ & All salt \\
\hline PC & 1.2 & Nal, $\mathrm{ZnCl}_{2}$, LMT \\
\hline PVC & $1.3-1.45$ & $\mathrm{ZnCl}_{2}$, LMT \\
\hline Polyester & $1.3-1.4$ & $\mathrm{ZnCl}_{2}$, LMT \\
\hline Nylon & $1.02-1.15$ & Nal, $\mathrm{CaCl}_{2}, \mathrm{ZnCl}_{2}, \mathrm{LMT}$ \\
\hline \multicolumn{3}{|c|}{$\begin{array}{l}\text { Note. polyethylene terephthalate (PET), high-densit } \\
\text { polyethylene (HDPE), polyvinyl chloride (PVC), low-densit } \\
\text { polyethylene (LDPE), and polypropylene (PP). Sodiun } \\
\text { chloride ( } \mathrm{NaCl} \text { ), sodium iodide (Nal), calcium chlorid } \\
\left(\mathrm{CaCl}_{2}\right) \text {, zinc chloride }\left(\mathrm{ZnCl}_{2}\right) \text {, and lithium metatungstat } \\
\text { (LMT). (from different sources). }\end{array}$} \\
\hline
\end{tabular}

\section{Microplastics Analysis}

\subsection{Enumeration}

The most common quantification technique to determine the abundance of microplastics in different environmental matrices is generally visual counting under a dissection microscope, binocular microscope, stereomicroscope, fluorescence microscope and scanning electron microscope (SEM). With the lower cost, using binocular microscope has limitation due to poor discrimination amongst the observed microplastics. Stereomicroscope and dissected microscope can provide a moderate resolution stereoscopy with adequate discriminability. Moreover, fluorescence microscope may result in a good resolution with accurate counting. Obviously, the use of SEM even without colour appearance provide a great resolution and spectroscopy to gain the surface characterization of microplastic. The limitation of the later technique is the high cost and few laboratory in Indonesia were equipped by SEM. For instance, Eriksen et al (2013) proved that $20 \%$ of identified plastic through ordinary microscope was later identified as aluminum silicate when identification was conducted by using SEM.

A particular attention should be made when working with muscle tissue, liver, gonad, cell, lymph system, moth, gill, and feces. To ensure material organic elimination, beside the use of an oxidant $\left(\mathrm{H}_{2} \mathrm{O}_{2}\right)$, some digestion solutions are recommended such as enzyme (Trypsin, Proteinase- $\mathrm{K}$ and Corolase 7089), acid $\left(\mathrm{HNO}_{3}, \mathrm{HCl}\right.$ and $\left.\mathrm{KOH}\right)$ and alkali $(\mathrm{NaOH})$ (Van Cauwenberghe et al., 2015; Qiu et al., 2016).

\subsection{Identification}

\subsubsection{Fourier Transform Infrared (FTIR) Spectroscopy}

Two type of FTIR have been used for microplastic identification including micro-FTIR (Frias et al., 2010) and ATR-FTIR (Avio et al., 2015; Syakti et al., 2017). Basically, For instance, spectra can be obtained using a Thermo Electron Nexus spectrometer equipped with a diamond crystal Smart Orbit $^{\top \mathrm{M}}$ accessory. Spectra were recorded in attenuated total reflection (ATR) and were corrected by the ATR correction of a specific software. All the spectra were acquired between 4000 and 450 $\mathrm{cm}^{-1}$ with 64 accumulations and a spectral resolution of $4 \mathrm{~cm}^{-1}$. Figure 2 showed an example of different polymers identification using FTIR.

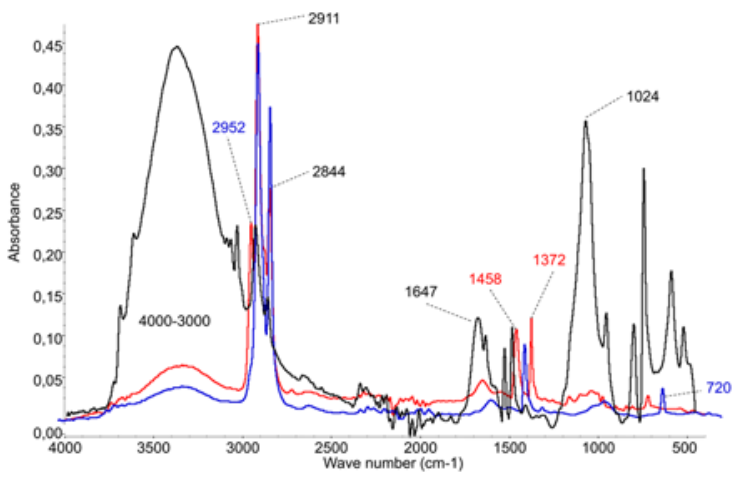

Figure 2. FTIR spectra for PP (red line), PE (blue line) and PS (black line) plastic polymers.

For instance, the peaks corresponded to the aromatic ring $(\mathrm{C}-\mathrm{H})$ stretching asymmetrical vibration (2911 and $\left.2844 \mathrm{~cm}^{-1}\right)$ indicated 
polymers PP and PE. PE can be easily identified by the $720 \mathrm{~cm}^{-1}$ band indicating methylene rocking in the $\mathrm{C}-\mathrm{H}$ out of plane bending region (Syakti et al., 2017).

\subsubsection{Pyr-GC/MS}

Nuelle et al. (2014) demonstrated the use of Pyrolysis-GC/MS (Pyr-GC/MS) by analyzing the thermal degradation product after pyrolysis at $700{ }^{\circ} \mathrm{Cfor} 60 \mathrm{~s}$ and then transferred into $\mathrm{GC} / \mathrm{MS}$ at $350{ }^{\circ} \mathrm{C}$. The identification will be based on comparison with common standard polymer and their degradation product. This technique is not only good indication for a specific plastic polymers but also can detect interference from organic plastic additives (Fries et al., 2013). The disadvantage by using this method is destruction of the analyzed materials.

\subsubsection{Raman Spectroscopy}

Lenz et al (2015) clearly demonstrated misidentification problems in the visual microscopic analysis of small microplastic can be resolved by using Raman spectroscopy. Raman spectroscopy reveals the chemical and structural composition of samples. They concluded that visual identification alone is inappropriate for studies on small microplastics. Sixty-eight percent of visually counted microplastics $(n=1279)$ were spectroscopically confirmed being plastic. The percentage varied with type, colour and size of the microplastics. Fibres had a higher success rate $(75 \%)$ than particles (64\%). Similar to the more widely known IR spectroscopy (Song et al., 2015), because of Raman scattering occurs when the monochromatic light source, such as a laser interacts with molecular vibrations, Raman spectroscopy can also identify varying additive chemical composition, degradation state and organic matter coating.

\section{Microplastic research in Indonesia}

Indonesia has a national action plan for combating Marine Plastic Debris (2017-2025) under the coordination of the Ministry of Maritime Affairs. However, microplastic research has not yet become a national priority. While the government focuses on marine debris management, several agencies such as the Indonesian Institute of Science (LIPI), Bogor Agricultural University (IPB), Jenderal Soedirman University (UNSOED), Raja Ali Haji Maritime University (UMRAH), Mulawarman University (UNMUL), Padjajaran University
(UNPAD) and the Agency for the Assessment and Application Technology (BPPT) have been conducting plastic research and monitoring. LIPI recently completed its microplastic sampling programme (2015-2017) with microplastics sampled from over 10 stations nationwide, and in 2016 published a paper on microplastics in deep-sea sediment (Cordova and Wahyudi, 2016). IPB and UNMUL have conducted the study on sediment microplastics respectively at Jakarta Bay (Manalu e al., 2017) and Muara Badak, Kutai Kartanegara (Dewi et al., 2015). The University Hasanuddin Makassar reported a study of microplastic debris, conducted in 2015 (Rochman et al., 2015), in fish and bivalves sold for human consumption while the Padjajaran University is conducting microplastics study at Seribu Islands, South of Java, Banten and North Java. In Cilacap water, UNSOED, UMRAH and Aix Marseille Univesity (France) conducted a joint research program and focused on five main aspects, including beach macro-litter monitoring, microplastic monitoring (Syakti et al., 2017); co-pollutions occurrence (such as polycyclic aromatic hydrocarbons-PAHs, polychlorinated biphenyls-PCBs and heavy metals) (Frias et al., 2010; Syakti et al., 2013); ingested plastic by fish; and community empowerment programme on re-use of plastic litter.

\section{Concluding Remarks and Future Trends}

To conclude, we started with a fundamental question, Do microplastic pose a significant threat to our marine ecosystem? To better answer that we must first understand the composition, the extent and the transformation of plastic during weathering or human-impacted process. Globally our analytical methods are evolving but Indonesian scientists still have a large gap due to the inadequate research infrastructures and our knowledge in this subject. Enumeration methods using binocular microscopes is time-consuming and might introduce large errors due to difficulties to distinguish between microplastics and other small particle materials.

Further research should be developed more particularly in relation to bioaccumulation and biomagnifications occurrence. Ingested microplastics can be transferred from lower trophic level to the higher trophic levels. Such a risk may become greater when co-pollution from other pollutant agents e.g. polycyclic aromatic hydrocarbons-PAHs, polychlorinated biphenyls-PCBs and heavy metals adsorbed onto plastic surface polymers. 
5 Omni-Akuatika Vol. 13 No. 2 November 2017: 1 - 6

\section{Acknowledgement}

The author thanks for the financial support from DIPA UNSOED (DIPA/023.04.2. 189899.2014)

\section{References}

Avio, C.G., Gorbi, S., Regoli, F., 2015. Experimental development of a new protocol for extraction and characterization of microplastics in fish tissues: first observation in commercial species from Adriatic Sea. Marine Environmental Research 111: 18-26.

CMMA [Coordinating Ministry for Maritime Affairs - Republic of Indonesia]., 2017. Indonesia's plan of action on marine plastic debris 2017-2025.

Cole, M., Lindeque, P., Fileman, E., Halsband, C., Goodhead, R., Moger, J., Galloway, T.S., 2013. Microplastic ingestion by zooplankton. Environmental Science and Technology 47 (12): 6646-6655.

Cole, M., Webb, H., Lindeque, P.K., Fileman, E.S., Halsband, C., Galloway, T.S., 2014. Isolation of microplastics in biota-rich seawater samples and marine organisms. Scientific Report 4: 2231-2236.

Corcorana, P.L., Norris, T., Ceccanesea, T., Walzak, M.J., Helm, P.A., Marvin, C. H., 2015. Hidden plastics of Lake Ontario, Canada and their potential preservation in the sediment record. Environmental Pollution 204: 17-25.

Cordoba, M. R., Wahyudi, A.J., 2015. Microplastic in the deep-sea sediment of southwestern Sumatera waters. Marine Research Indonesia 41 (1): 27-35.

Dewi, I.S., Budiarsa, A.A., Ritonga, I.R. 2015. Distribusi mikroplastik pada sedimen di Muara Badak, Kutai Kartanegara. Depik 4 (3): 121-131.

DiSalvo, L.H., 1988. Observations on the larval and post-metamorphic life of Concholepas concholepas (Bruguiere, 1789) in laboratory culture. Veliger 30 (4): 358-368.

Eriksen, M., Mason, S., Wilson, S., Box, C., Zellers, A., Edwards, W., Farley, H., Amato, S., 2013. Microplastic pollution in the surface waters of the Laurentian great lakes. Marine Pollution Bulletin 77: 177182.

Eriksen, M., Liboiron, M., Kiessling, T., Charron, L., Alling, A., Lebreton, L., Richard, H., Roth, B., Ory, N.C., Hidalgo-Ruz, V., Meerhoff, E., Box, C., Cummins, A., Thiel, M., 2018. Microplastic sampling with the AVANI trawl compared to two neuston trawls in the Bay of Bengal and South Pacific. Environmental Pollution 232: 430439.

Frias, J.P. G.I., Sobral, P., Ferreira, A.M., 2010. Organic pollutant in microplastics from two beaches of the Portuguese coastal waters. Marine Pollution Bulletin 60: 19881992.

Fries, E., Dekiff, J.H., Willmeyer, J., Nuelle, M.T., Ebert, M., Remy, D., 2013. Identification of polymer types and additives in marine microplastics particles using pyrolysis-GC/MS and scanning electron microscopy. Environmental Science: Processes and Impacts 15: 1949-1956.

GESAMP., 2016. Sources, fate and effects of microplastics in the marine environment: part two of a global assessment. (Kershaw, P.J., and Rochman, C.M., eds). (IMO/FAO/UNESCO-

IOC/UNIDO/WMO/IAEA/UN/UNEP/UNDP Joint Group of Experts on the Scientific Aspects of Marine Environmental Protection). Rep. Stud. GESAMP No. 93, $220 \mathrm{pp}$.

Halstead, J.E., Smith, J;A., Carter, E.A., Lay, P.A., Johnston, E.L., 2018. Assesment tools for microplasticsand natural fibers ingested by fish in an urbanised estuary. Environmental Pollution 234: 552-561.

Jambeck, J.R., Geyer, R., Wilcox, C., Siegler, T.R., Perryman, M., Andrady, A., Narayan, R., Law, K.L., 2015. Plastic waste inputs from land into the ocean. Science 347 (6223): 768-771.

Leibezeit, G., Dubaish, F., 2012. Microplastics in beaches of the east Frisian Islands Spiekeroog and Kachelotplate. Bulletin Environmental Contamination and Toxicology 89: 213-217.

Lenz, R., Enders, K., Stedmon, C.A., Mackenzie, D.M., Nielsen, T.G., 2015. A 
critical assessment of visual identification of marine microplastic using Raman spectroscopy for analysis improvement. Marine Pollution Bulletin 100 (1): 82-91.

Lusher, A.L., McHugh, M., Thompson, R.C., 2013. Occurrence of microplastics in the gastrointestinal tract of pelagic and demersal fish from the English channel. Marine Pollution Bulletin 67: 94-99.

Lusher, A.L., Welden, N.A., Sobral, P., Cole, M., 2017. Sampling, isolating and identifying microplastics ingested by fish and invertebrates. Analytical Methods 9: 1346-1360.

KLHK [Kementrian Lingkungan Hidup dan Kehutanan]. Retrieved January 4, 2018, from www.menlhk.go.id.

Manalu, A.A., Hariyadi, S., Wardiatno, Y., 2017. Microplastic Abundance in Coastal Sediments of Jakarta Bay, Indonesia. AACL Bioflux 10 (5): 1164-1173.

Mathalon, A., Hill, P., 2014. Microplastics fibers in the intertidal ecosystems surrounding Halifax Harbor, Nova Scotia. Marine Pollution Bulletin 81: 69-79.

Nuelle, M.T., Dekiff, J.H., Rem, D., Fries, E. 2014. A new analytical approachfor monitoring microplastics in marine sediments. Environmental Pollution 184: 161-169.

Osswald, T.A., Baur, E., Brinkmann, S. 2006. International Plastics Handbook. Hanser. German. P. 471.

PlasticsEurope., 2016. Plastic - the Facts 2016. An Analysis of European Plastics Production, Demand and Waste Data. Plastics Europe, Brussels, Belgium. Retrieved Dec 23 , 2017, from http://www.plasticseurope.org/Document/pl astics--the-facts-2016.aspx

Qiu, Q., Peng, J., Yu, X., Chen, F., Wang, J., Dong, F. 2015. Occurrence of microplastics in the coastal marine environment: first observation on sediment of China. Marine Pollution Bulletin 98: 274280.

Qiu, Q., Tan, Z., Wang, J., Peng, J., Li, M., Zhan, Z., 2016. Extraction, enumeration and identification methods for monitoring microplastics in the environment. Estuarine, Coastal and Shelf Science 176: 102-109.

Song, Y.K., Hong, S.H., Jang, M., Han, G.M., Rani, M., Lee, J., Shim, W.J., 2015. A comparison microscopic and spectrosco^pic identification methods for analysis of microplastics in environmental samples. Marine Pollution Bulletin 93: 202209.

Syakti, A.D., Hidayati, N.V., Hilmi, E., Piram, A., Doumenq, P., 2013. Source apportionment of sedimentary hydrocarbons in the Segara Anakan Nature Reserve, Indonesia. Marine Pollution Bulletin 74 (1): 141-148.

Syakti, A.D., Bouhroum, R., Hidayati, N.V., Koenawan, C.J., Boulkamh, A., Sulistyo, I., Lebarillier, S., Akhlus, S., Doumenq, P., Wong-Wah-Chung, P., 2017. Beach macro-litter monitoring and floating microplastic in a coastal area of Indonesia. Marine Pollution Bulletin 122: 217-225.

Rochman, C.M., Tahir, A., Williams, S.L., Baxa, D. V., Lam, R., Miller, J.T., Teh, F.C., Werorilangi, S., Teh, S.J., 2015. Anthropogenic debris in seafood: Plastic debris and fibers from textiles in fish and bivalves sold for human consumption. Scientific Report 5: 14340.

Steer, M., Cole, M., Thompson, R.C., Lindeque, R.K., 2017. Microplastic ingestion in fish larvae in the western English Channel. Environmental Pollution 226: 250-259.

UNEP., 2016. Marine plastic debris and microplastics - Global lessons and research to inspire action and guide policy change. United Nations Environment Programme, Nairobi.

Van Cauwenberghe, L., Devriese, L., Galgani, F., Robbens, J., Janssen, C.R., 2015. Microplastics in sediments: A review of techniques, occurrence and effects. Marine Environmental Research 111: 517.

Wessel, C.C., Lockridge, G.R., Battiste, D., Cebrian, J., 2016. Abundance and characteristics of microplastics in beach sediments: Insights into microplastic accumulation in northern Gulf of Mexico estuaries. 